\title{
DIGLOSIA
}

Terakreditasi Sinta 3 | Volume 3 | Nomor 2 | Tahun 2020 | Halaman 197-210

P-ISSN 2615-725X | E-ISSN 2615-8655

http://diglosiaunmul.com/index.php/diglosia/article/view/43

\section{PERANAN KETERAMPILAN MEMBACA PADA PROSES PRAPENERJEMAHAN DALAM MENCAPAI KESEPADANAN TEKS TERJEMAHAN}

\author{
The Role of Reading Skills in the Pre-Translation Process in Achieving \\ the Translation Equivalence
}

\author{
Maya Rahmawati,* ${ }^{1, *}$ an Sidik Indra Nugraha ${ }^{2}$ \\ ${ }^{1,2}$ Universitas Singaperbangsa Karawang \\ Jalan H. S. Ronggowaluyo Karawang \\ Pos-el Korespondensi: maya.rahmawati@fkip.unsika.ac.id
}

\begin{abstract}
This study examines what strategies are most likely to be used by students when translating as well as the equivalence level of the translated texts. It aims to find out the appropriate reading strategy when translating. This study uses a qualitative paradigm because it seeks to explain a phenomenon about the choice of reading strategies used by students and the equivalence equivalence level of the translated texts. This research produces descriptive data in the form of patterns of reading strategy when students translate two different kinds of texts. In this study, data collection was carried out in two ways, namely questionnaires and translating test. Questionnaire was used to obtain data about the reading strategies chosen by students when translating. The questionnaire used is a closed type in the form of multiple choice. Each item has a different value. From the results of the analysis presented, it can be seen that most students still show a tendency to use bottom-up strategies in the process of translating. In addition, it can be seen that the choice of reading strategy can influence the results of translation. Some translations produced by students who tend to use bottom-up strategies in the translation process are not context-specific and still seem hard to read and unnatural. While around $80 \%$ of translations resulting from top-down strategies are considered acceptable because they are in accordance with the rules of the target language and sentence context. In addition, this research can also show that relying solely on one reading strategy can potentially produce erroneous translations.
\end{abstract}

Keywords: reading skill, reading strategy, equivalence, translation

Abstrak: Penelitian ini mengkaji strategi yang cenderung paling banyak digunakan oleh mahasiswa ketika menerjemahkan serta bagaimana kesepadanan terjemahan yang dihasilkan. Tujuannya adalah untuk menemukan strategi membaca yang tepat pada saat menerjemahkan. Penelitian ini menggunakan paradigma kualitatif karena berusaha untuk menjelaskan sebuah fenomena tentang pilihan strategi membaca yang digunakan oleh mahasiswa beserta kesepadanan hasil terjemahan. Penelitian ini menghasilkan data non-numerik berupa pola penggunaan strategi membaca ketika mahasiswa menerjemahkan dua jenis teks. Dalam penelitian ini, pengumpulan data dilakukan melalui dua cara, yaitu kuesioner dan soal tes menerjemahkan. Kuesioner digunakan untuk memperoleh data mengenai strategi membaca yang dipilih mahasiswa ketika menerjemahkan. Kuesioner yang digunakan bersifat tertutup dalam bentuk pilihan ganda. Setiap butirnya memiliki bobot yang berbeda. Dari hasil analisis diketahui bahwa sebagian besar mahasiswa masih menunjukkan kecenderungan untuk menggunakan strategi bottom-up dalam proses menerjemahkan. Selain itu, dapat diketahui bahwa pilihan strategi membaca bisa mempengaruhi hasil terjemahan. Beberapa terjemahan yang dihasilkan oleh mahasiswa yang cenderung menggunakan strategi bottom-up dalam proses penerjemahan tidak sesuai konteks dan masih terkesan kaku dan tidak luwes. Sementara 80\% terjemahan yang dihasilkan dari strategi top-down dianggap berterima karena sesuai dengan kaidah bahasa sasaran dan konteks kalimat. Selain itu, penelitian ini juga dapat menunjukkan bahwa ketika penerjemah sepenuhnya bergantung hanya pada salah satu strategi membaca dapat berpotensi menghasilkan terjemahan yang keliru.

Kata Kunci: keterampilan membaca, strategi membaca, kesepadanan, terjemahan 


\section{A. PENDAHULUAN}

Membaca merupakan salah satu tahapan penting dalam proses penerjemahan. Ketika akan menerjemahkan sebuah teks, penerjemah diharuskan membaca dengan saksama dan mendalam agar pesan yang terkandung dalam teks tersebut dapat dipahami dengan baik dan tidak terjadi penyimpangan makna pada saat diterjemahkan. Setelah berhasil menangkap pesan teks sumber (TSu), penerjemah baru dapat mengalihkan pesan ke dalam bahasa sasaran (BSa). Oleh karena itu, keterampilan membaca dapat dikatakan wajib dimiliki oleh seorang penerjemah karena akan menunjang keberhasilannya dalam menyampaikan pesan sehingga TSa yang dihasilkan sepadan dengan TSu.

Sayangnya, dari pengamatan selama mengajar mata kuliah penerjemahan banyak mahasiswa yang mengabaikan proses membaca. Rata-rata mahasiswa masih terjebak dalam pandangan sempit mengenai penerjemahan, yakni inti dari kegiatan menerjemahkan adalah mengubah bahasa. Hal ini dapat diketahui setiap kali mereka diberikan tugas menerjemahkan teks. Yang mereka lakukan pertama kali adalah langsung membuka kamus tanpa membaca teksnya terlebih dahulu. Meskipun pada hakikatnya menggunakan kamus adalah hal yang boleh dan lazim dalam penerjemahan, mengandalkannya 100\% tanpa bantuan nalar kebahasaan sangat tidak dianjurkan.

Pada hakikatnya strategi membaca yang tepat untuk menerjemahkan adalah dengan menggunakan kombinasi dua strategi umum membaca, yaitu model bottom-up dan top-down (Colina, 2015, hlm.178). Dengan menggunakan model yang pertama proses membaca dimulai dari memahami bagian yang kecil ke bagian yang lebih besar (dari kata ke kalimat ke paragraf kemudian teks). Sementara dengan menggunakan model yang kedua, proses membaca tidak sepenuhnya bergantung pada pengetahuan kata per kata, melainkan lebih mengandalkan latar belakang pengetahuan atau background knowledge yang telah dimiliki pembaca. Kombinasi yang tepat dari kedua model ini diperlukan karena dua alasan: pertama, proses membaca akan menjadi lebih menyeluruh karena terjadi sebuah proses membaca yang interaktif, yakni pembaca mampu menghubungkan pengetahuan yang sudah dimiliki dengan pengetahuan yang baru, dan kedua, kemungkinan adanya elemen teks yang ditambah-tambahkan atau dikurangi dapat dihindari karena pembaca juga tidak luput dari memperhatikan satuan bahasa yang kecil seperti kata atau frasa. Dua keunggulan ini mampu membantu penerjemah menghasilkan terjemahan yang sepadan.

Untuk membantu mahasiswa memahami teks dalam proses penerjemahan, penggunaan kombinasi kedua strategi membaca tersebut penting untuk dilakukan di dalam kelas penerjemahan. Akan tetapi, literatur yang membahas mengenai strategi tersebut belum secara pasti menjabarkan proporsi penggunaan keduanya dalam penerjemahan: apakah harus lebih cenderung menggunakan strategi bottom-up untuk menerjemahkan satu teks tertentu dan strategi top-down untuk jenis teks lainnya? Apakah dampaknya terhadap hasil terjemahan jika salah satu strategi cenderung lebih banyak digunakan daripada yang lain?. Dengan adanya pertanyaan-pertanyaan yang belum terjawab tersebut maka sebuah analisis mendalam perlu dilakukan. Penelitian ini akan mengkaji strategi apa yang cenderung paling banyak digunakan oleh mahasiswa ketika menerjemahkan serta dampaknya terhadap hasil terjemahan.

Mengingat pentingnya peranan membaca dalam proses penerjemahan, beberapa pakar telah mengemukakan strategi membaca untuk keperluan menerjemahkan. Newmark (1988) merumuskan dua cara yang biasa dilakukan 
untuk menerjemahkan. Pertama, membaca sekaligus menerjemahkan kalimat per kalimat sekitar satu paragraf atau satu bab untuk mengetahui gaya bahasa yang digunakan dalam teks tersebut, barulah kemudian membaca teks secara keseluruhan. Cara kedua adalah dengan membaca TSu secara keseluruhan dua sampai tiga kali, kemudian menganalisis tujuan, register, gaya, menandai kata-kata dan bagian yang sulit, kemudian baru menerjemahkan ketika benar-benar sudah paham isi dan tujuan penerjemahan teks tersebut.

Colina (2015), tidak jauh berbeda dengan Newmark, mengelompokkan strategi membaca ke dalam dua kategori, yaitu bottom up dan top-down. Dengan model bottom up penerjemah memulai proses membacanya dari satuan bahasa yang terkecil ke yang lebih besar, seperti dari mulai memahami arti kata kemudian kalimat kemudian paragraf dan terakhir memahami wacana secara keseluruhan. Sebaliknya, dengan menggunakan model top-down, penerjemah tidak perlu mengetahui arti kata per kata yang ada di dalam teks, karena ia dibantu oleh pengetahuan yang telah dimiliki sebelumnya, informasi kontekstual, dan strategi tingkat tinggi lainnya untuk memahami teks.

Meskipun konsep kedua pakar di atas tampak sama, kadar perhatian keduanya terhadap esensi membaca dalam proses membaca berbeda. Newmark membahasnya tidak lebih dari tiga paragraf pada bab tentang proses penerjemahan. Sementara Colina (2015) memberikan perhatian sangat khusus terhadap proses membaca sehingga ia mendedikasikan satu bab dalam bukunya mengenai pemahaman membaca dan penerjemahan. Oleh karena itu, peneliti memutuskan untuk menggunakan konsep yang dikemukakan oleh Colina sebagai dasar pijakan untuk analisis dalam penelitian ini.

\section{B. METODE}

Penelitian ini menggunakan pendekatan kualitatif. Menurut Merriam (2009) pendekatan ini memiliki setidaknya empat karakteristik: (1)fokus pada proses, pemahaman, dan pemaknaan; (2) Peneliti adalah instrumen utama dalam pengumpulan dan analisis data; (3) prosesnya bersifat induktif; dan (4) hasilnya bersifat deskriptif. Empat karakteristik tersebut tercermin dalam penelitian ini karena berusaha untuk menjelaskan sebuah fenomena tentang pilihan strategi membaca yang digunakan oleh mahasiswa beserta dampaknya terhadap hasil terjemahan. Penelitian ini menghasilkan data deskriptif berupa pola penggunaan strategi membaca ketika mahasiswa menerjemahkan beberapa jenis teks.

Subjek penelitian di dalam penelitian ini adalah mahasiswa semester 5 program studi Pendidikan Bahasa Inggris UNSIKA yang mengambil peminatan penerjemahan. Terdapat sekitar 120 mahasiswa dari 3 kelas mata kuliah pilihan penerjemahan. Dari total populasi tersebut, 30 orang mahasiswa dijadikan sampel dalam penelitian ini. Alasan mereka dipilih sebagai subjek karena mereka memang memiliki minat lebih besar terhadap penerjemahan dan topik penelitian ini secara khusus mengkaji strategi membaca yang digunakan oleh mahasiswa ketika menerjemahkan.

Ada beberapa teknik pengumpulan data yang dapat digunakan dalam penelitian. Sebagaimana yang diuraikan Sugiyono (2013) bahwa pengumpulan data dapat dilakukan melalui hasil wawancara, observasi, dokumentasi, dan gabungan/triangulasi. Dalam penelitian ini, pengumpulan data dilakukan melalui dua cara, yaitu kuesioner dan soal tes menerjemahkan. Kuesioner dan digunakan untuk memperoleh data mengenai strategi membaca yang dipilih mahasiswa ketika menerjemahkan. Kuesioner yang digunakan bersifat 
tertutup dalam bentuk pilihan ganda. Setiap butirnya memiliki bobot yang berbeda. Butir yang menjadi indikator penggunaan strategi bottom-up diberi bobot 5. Sementara butir yang menjadi indikator penggunaan strategi top-down diberi bobot 10. Kemudian, skala penskoran disusun. Nilai 0-55 masuk ke dalam kategori strategi bottom-up dan nilai 60 masuk ke dalam kategori strategi top-down. Tes menerjemahkan diberikan untuk mengetahui pola penggunaan strategi dan kesepadanannya.

\section{PEMBAHASAN}

Secara umum, ada dua strategi untuk membaca yaitu pendekatan top-down dan bottom-up. Idealnya, kedua pendekatan ini digunakan ketika membaca terutama untuk keperluan memahami teks yang akan diterjemahkan. Jika salah satunya lebih dominan, dikhawatirkan ada kekeliruan dalam memahami teks yang akan berakibat pada kualitas terjemahan. Pada subbab ini akan dijelaskan data yang diperoleh tentang strategi membaca yang digunakan mahasiswa ketika menerjemahkan. Ada dua jenis teks yang digunakan, yaitu teks ekspositori dan teks naratif.

\section{Strategi Membaca Teks Ekspo- sitori}

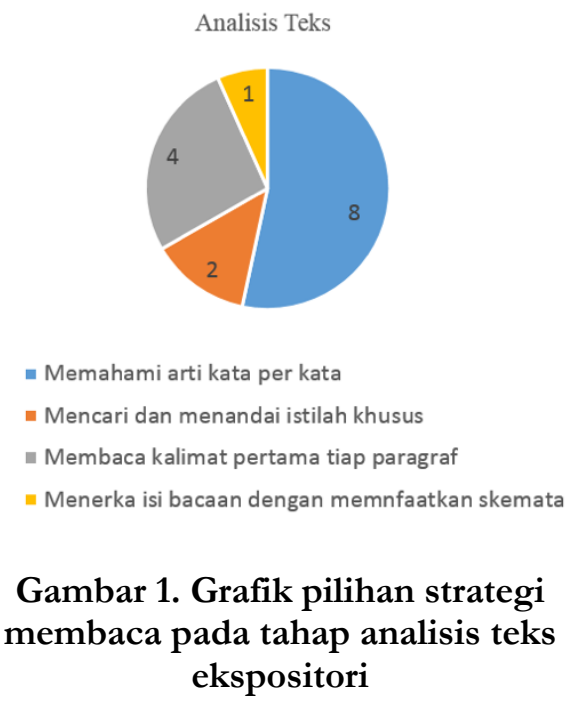

Grafik di atas menjelaskan pilihan strategi membaca pada tahap analisis teks. Dalam penerjemahan, proses pertama yang dilakukan ketika menerjemahkan sebuah teks adalah melakukan analisis teks secara menyeluruh. Tahapan ini meliputi analisis struktur gramatikal dan semantis. Hal ini diperlukan agar penerjemah mendapatkan gambaran mengenai topik maupun sasaran pembacanya. Grafik di atas menunjukkan bahwa sebagian besar mahasiswa memilih menggunakan pendekatan bottom-up dalam tahap ini. Sekitar 53\% dari mereka memilih mencoba memahami arti kata per kata ketika menganalisis teks dan 13\% lainnya mencari dan menandai istilah khusus. Untuk pendekatan top-down, ada $26 \%$ yang memilih membaca kalimat pertama setiap paragraf dan hanya $6 \%$ saja yang mencoba menerka isi teks dengan membaca judul dan menghubungkannya dengan pengetahuan yang telah dimiliki. Dengan demikian, karena sebagian besar responden cenderung menggunakan pendekatan bottom-up, maka mereka dipastikan akan kesulitan menangkap pesan yang terkandung di dalam teks apabila harus menerjemahkan dalam waktu yang terbatas seperti untuk latihan di kelas atau ketika tes menerjemahkan.

Tahap pengalihan

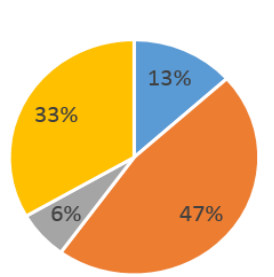

$$
\begin{aligned}
& \text { - Menghubungkan ide pokok setiap paragraf } \\
& \text { - Membaca artikel secara berulang } \\
& \text { - Membuat catatan poin penting } \\
& \text { = Mencari arti setiap kata di kamus }
\end{aligned}
$$

\section{Gambar 2. Grafik pilihan strategi} membaca pada tahap pengalihan 
Grafik di atas menunjukkan pilihan strategi membaca pada tahap pengalihan. Dalam penerjemahan, setelah proses analisis teks selanjutnya adalah proses pengalihan. Tahapan ini bersifat abstrak karena berlangsung dalam benak penerjemah. Di tahap ini penerjemah mencoba mencerna segala informasi yang diperolah pada tahap pertama untuk mendapatkan makna yang utuh. Hal ini diperlukan agar penerjemah dapat memastikan pesan TSu tidak ada yang keliru dipahami. Grafik di atas menunjukkan bahwa sebagian besar mahasiswa memilih menggunakan pendekatan bottom-up dalam tahap ini. Sekitar $47 \%$ dari mereka memilih membaca teks secara berulang pada saat proses pengalihan dan 33\% lainnya mencari arti setiap kata di kamus. Untuk pendekatan top-down, ada 13\% yang memilih menghubungkan ide pokok setiap paragraf dan hanya $6 \%$ saja yang membuat catatan penting pada saat tahap pengalihan. Dengan demikian, karena sebagian besar responden cenderung menggunakan pendekatan bottom-up, pesan atau makna yang ditangkap bisa jadi tidak utuh dan mereka akan kesulitan melihat koherensi teks yang akan sangat berpengaruh pada hasil terjemahan.

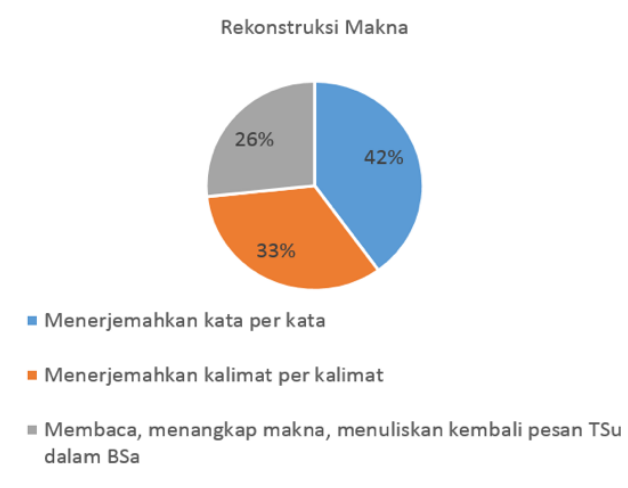

\section{Gambar 3. Grafik pilihan strategi menerjemahkan dalam tahap rekonstruksi makna}

Berbeda dengan grafik sebelumnya, kali ini grafik di atas menunjukkan pilihan strategi menerjemahkan dalam tahap rekonstruksi makna. Setelah pengalihan, yaitu pada saat penerjemah sudah mengetahui dan memahami keseluruhan pesan TSu, maka selanjutnya adalah tahap rekonstruksi makna. Di tahap ini penerjemah menuangkan kembali makna yang terkandung dalam TSu menggunakan BSa. Pada tahap ini akan terlihat apakah penerjemah sudah memahami makna secara utuh. Dari grafik di atas dapat diketahui bahwa untuk strategi menerjemahkan sebagian besar mahasiswa masih cenderung menerjemahkan kata per kata yaitu sebanyak 42\%. Fakta ini memperkuat bahwa strategi membaca yang paling dominan digunakan dalam proses penerjemahan adalah strategi bottom-up.

\section{Strategi Membaca Teks Naratif}

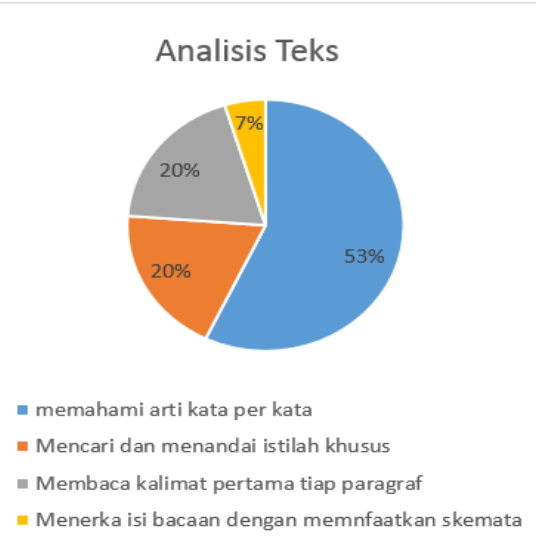

\section{Gambar 4. Grafik pilihan strategi membaca pada tahap analisis teks naratif}

Pada tahap analisis teks dalam proses penerjemahan teks naratif strategi membaca yang paling banyak digunakan tidak berbeda dari yang digunakan dalam menerjemahkan teks ekspositori, yaitu strategi bottom-up. Sekitar 53\% dari mereka memilih mencoba memahami arti kata per kata ketika menganalisis teks dan 20\% lainnya mencari dan menandai istilah khusus. Untuk pendekatan top-down, ada $20 \%$ yang memilih membaca kalimat pertama setiap paragraf dan hanya $7 \%$ saja 
yang mencoba menerka isi teks dengan membaca judul dan menghubungkannya dengan pengetahuan yang telah dimiliki.

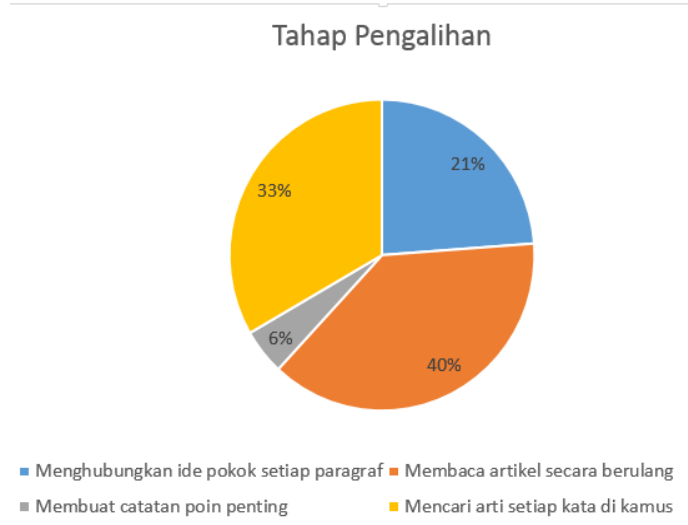

\section{Gambar 5. Grafik pilihan strategi membaca pada tahap pengalihan}

Secara garis besar strategi membaca yang digunakan pada tahap pengalihan ini tidak jauh berbeda dengan yang digunakan untuk menerjemahkan teks ekspositori. Grafik di atas menunjukkan bahwa sebagian besar mahasiswa memilih menggunakan pendekatan bottom-up. Sekitar 40\% dari mereka memilih membaca teks secara berulang pada saat proses pengalihan dan 33\% lainnya mencari arti setiap kata di kamus. Untuk pendekatan top-down, ada sedikit peningkatan pada persentase yang memilih menghubungkan ide pokok setiap paragraf, yaitu dari $13 \%$ menjadi $20 \%$. Sementara yang membuat catatan penting pada saat tahap pengalihan masih pada angka yang sama, yaitu hanya $6 \%$.

Berbeda dengan grafik sebelumnya, kali ini grafik di bawah ini menunjukkan pilihan strategi menerjemahkan dalam tahap rekonstruksi makna. Setelah pengalihan, yaitu pada saat penerjemah sudah mengetahui dan memahami keseluruhan pesan TSu, maka selanjutnya adalah tahap rekonstruksi makna. Di tahap ini penerjemah menuangkan kembali makna yang terkandung dalam TSu menggunakan BSa. Pada tahap ini akan terlihat apakah penerjemah sudah memahami makna secara utuh. Dari grafik di atas dapat diketahui bahwa untuk strategi menerjemahkan sebagian besar mahasiswa masih cenderung menerjemahkan kata per kata yaitu sebanyak 42\%. Fakta ini memperkuat bahwa strategi membaca yang paling dominan digunakan dalam proses penerjemahan adalah strategi bottom-up.
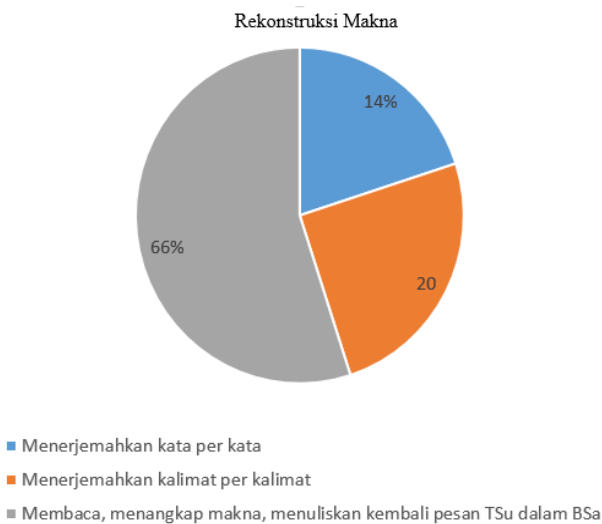

\section{Gambar 6. Grafik pilihan strategi menerjemahkan dalam tahap rekonstruksi makna}

\section{Kualitas Terjemahan Teks Ekspositori}

Setelah mengetahui strategi membaca yang digunakan oleh mahasiswa pada saat proses penerjemahan, kali ini yang dijabarkan adalah bagaimana kualitas hasil terjemahan. Kualitas tersebut dilihat dari beberapa kategori kesepadanan yang dirumuskan oleh Baker 0 yaitu kesepadanan tataran kata, kesepadanan di atas tataran kata, dan kesepadanan gramatikal. Ada dua jenis teks yang digunakan yaitu teks ekspositori dan teks naratif berupa cerita pendek.

\section{a. Kesepadanan Tataran Kata}

Tabel 1 menunjukkan hasil terjemahan dari mahasiswa yang cenderung menggunakan strategi membaca top-down (TETD) dan bottom-up (TEBU). 
Tabel 1. Kesepadanan Tataran Kata

\begin{tabular}{ccc}
\hline & TSu & TSa \\
\hline TEBU11 & $C V$ & CV \\
TEBU12 & & Daftar Riwayat Hidup \\
TEBU13 & & Riwayat Hidup \\
TETD11 & $C V$ & Daftar Riwayat Hidup \\
TETD12 & & Daftar Riwayat Hidup \\
TETD13 & & Surat Lamaran Pekerjaan \\
\hline
\end{tabular}

CV yang merupakan akronim dari Curriculum Vitae adalah kata yang sudah sangat dikenal luas oleh pembaca sasaran (bahasa Indonesia). Yang menarik, meskipun sudah tidak asing, ditemukan pilihan padanan yang cukup beragam pada hasil terjemahan mahasiswa. TEBU yang biasanya bergantung pada penerjemahan kata per kata ada yang menggunakan kata pinjaman $C V$, daftar riwayat hidup, dan riwayat hidup. Ketiga padanan tersebut memiliki tingkat keterbacaan yang tinggi karena dapat mudah dipahami pembaca. Sementara itu, yang menggunakan TETD, ada satu padanan yang dianggap kurang berterima karena beda acuan. $C V$ biasanya berisi tentang data personal seseorang lengkap dengan latar belakang pendidikan, pengalaman bekerja, dan prestasi-prestasi. Sementara surat lamaran pekerjaan mengacu pada surat resmi sebagai pengantar yang ditulis seseorang untuk menyampaikan maksud melamar pekerjaan. Kemungkinan terjadinya kekeliruan ini adalah mahasiswa terlalu bergantung pada pengetahuan sebelumnya. Yang mungkin ada di benaknya ketika melihat kata $C V$ adalah bahwa itu berkaitan dengan lamaran pekerjaan sehingga padanan yang dipilihnya adalah surat lamaran pekerjaan.

Tabel 2. Kesepadanan Tataran Kata

\begin{tabular}{ccc}
\hline & TSu & TSa \\
\hline TEBU21 & Employer & Para karyawan \\
TEBU22 & & Karyawan \\
TEBU23 & & Majikan \\
TETD21 & Employer & Penyalur tenaga kerja \\
TETD22 & & Manajer \\
TETD23 & & Seorang atasan \\
\hline
\end{tabular}

Employer pada dasarnya adalah kata yang bersifat universal namun seringkali diperlukan kemampuan memahami konteks untuk menemukan padanan yang tepat. Menurut kamus daring Oxford, makna kata employer adalah "a person or company that pays people to work for them". Sementara menurut kamus daring InggrisIndonesia (kamus.net) ada tiga pilihan arti kata employer, yaitu atasan, majikan, tauke. Padanan yang diberikan oleh mahasiswa yang memilih menggunakan bottom-up adalah para karyawan, karyawan, dan majikan. Karyawan tentu bukan padanan yang tepat karena secara komponen makna jelas berbeda dengan employer. Sementara majikan sebetulnya secara makna benar, tetapi untuk konteks artikel populer tentang bagaimana cara membuat CV kata tersebut kurang tepat. Mahasiswa yang cenderung menggunakan strategi topdown memberikan padanan penyalur tenaga kerja, manajer, dan seorang atasan. Untuk mengetahui padanan apa yang lebih tepat, berikut ini adalah kalimat lengkapnya: People should remember that an employer typically spends between 15 and 30 seconds scanning each $C V$ and you have that one chance to make an impression". Dari kalimat ini dapat dipahami bahwa pesan utamanya adalah tentang bagaimana melakukan rekrutmen tenaga kerja. Dengan demikian, di antara beberapa padanan yang diberikan yang cukup berterima sesuai konteks adalah manajer atau seorang atasan. Jika dilakukan penelusuran lebih jauh, maka ada padanan yang lebih tepat karena sudah spesifik terkait bidangnya yaitu, manajer $S D M$ atau tim HRD. Akan tetapi manajer atau atasan dapat dianggap memiliki beberapa komponen makna yang sama. Pada data ini, terlihat bahwa bergantung mengandalkan satu strategi membaca yaitu bottom-up saja bisa berakibat pada kesalahan makna atau ketidaksesuaian padanan dengan konteks. 


\section{b. Kesepadanan di Atas Tataran Kata}

Tabel 3. Kesepadanan di Atas Tataran Kata

\begin{tabular}{ccc}
\hline & TSu & TSa \\
\hline TEBU31 & $\begin{array}{c}\text { Recruitment } \\
\text { Company }\end{array}$ & $\begin{array}{c}\text { Rekrutmen } \\
\text { perusahaan } \\
\text { Pengerahan pabrik }\end{array}$ \\
TEBU32 & & Perusahaan \\
TEBU33 & & Rekrutmen \\
& & Perusahaan \\
TETD31 & Recruitment & Perekrutan tenaga \\
& Company & kerja \\
TETD32 & & Perusahaan \\
& & rekrutmen \\
TETD33 & & Perusahaan yang \\
& & menerima tenaga \\
& & baru \\
\hline
\end{tabular}

Recruitment company atau yang tertulis dalam wikipedia sebagai employement agency adalah "An employment agency is an organization which matches employers to employees." Dari pengertian tersebut dapat dipahami bahwa recruitment company adalah agen yang bergerak dalam bidang pencarian atau perekrutan karyawan. Frasa ini diterjemahkan cukup beragam, dari yang masih mempertahankan dalam bentuk frasa sampai dengan yang mencoba memberikan padanan dalam bentuk klausa. Dari padanan versi strategi bottom-up, Rekrutmen Perusahaan dan Pengerahan Perusahaan secara makna berbeda dengan recruitment company. Sementara padanan dari strategi top-down yang dianggap kurang tepat adalah TETD33, yaitu perusabaan yang menerima tenaga baru. Selain secara makna atau fungsi berbeda, bentuknya yang berupa klausa menjadikannya tidak efisien. Yand dianggap berterima adalah Perusabaan rekrutmen dan perusahaan perekrutan tenaga kerja.

Pada data ini ada perbedaan kualitas padanan yang cukup signifikan antara yang dihasilkan oleh mahasiswa yang menggunakan strategi membaca bottom up dan top-down. Pertama, pada data TEBU41-TEBU43, semuanya menerjemahkan they menjadi mereka. Sementara pada data dari grup TETD they tidak diterjemahkan mereka melainkan daftar riwayat bidup mereka, daftar riwayat bidup tersebut, dan CV mereka.

Tabel 4. Kesepadanan di Atas Tataran Kata

\begin{tabular}{|c|c|c|}
\hline & TSu & TSa \\
\hline TEBU41 & $\begin{array}{c}\text { They are } \\
\text { literally dead on } \\
\text { arrival }\end{array}$ & $\begin{array}{c}\text { Mereka benar- } \\
\text { benar gagal } \\
\text { sebelum datang }\end{array}$ \\
\hline TEBU42 & & $\begin{array}{c}\text { Seolah mereka } \\
\text { mati sebelum } \\
\text { pulih }\end{array}$ \\
\hline TEBU43 & & $\begin{array}{c}\text { Mereka benar- } \\
\text { benar mati pada } \\
\text { saat tiba }\end{array}$ \\
\hline TETD41 & $\begin{array}{c}\text { They are } \\
\text { literally dead on } \\
\text { arrival }\end{array}$ & $\begin{array}{c}\text { Daftar riwayat } \\
\text { hidup mereka } \\
\text { telah ditolak } \\
\text { sejak awal }\end{array}$ \\
\hline TETD42 & & $\begin{array}{c}\text { Daftar riwayat } \\
\text { hidup tersebut } \\
\text { telah ditolak } \\
\text { sejak awal }\end{array}$ \\
\hline TETD43 & & $\begin{array}{c}\text { CV mereka } \\
\text { langsung ditolak } \\
\text { saat melamar } \\
\text { kerja. }\end{array}$ \\
\hline
\end{tabular}

Pada bagian ini dapat terlihat bagaimana strategi top-down membantu mereka memahami sebuah kata dengan lebih menyeluruh yaitu dengan mempertimbangkan konteks dan mencari tahu ke mana kata they mengacu sehingga padanan yang dihasilkan lebih mudah dipahami. Selanjutnya, perbedaan yang cukup signifikan lainnya juga dapat kita temukan pada bagian literally dead. Pada kalimat ini kata dead mengandung makna figuratif. Oleh karena itu, kurang tepat apabila diterjemahkan secara literal sebagaimana ditemukan pada TEBU42 dan TEBU43. Padanan yang dianggap berterima karena memiliki tingkat keterbacaan yang tinggi adalah gagal dan ditolak. 


\section{c. Kesepadanan Gramatikal}

Tabel 5. Kesepadanan Gramatikal

\begin{tabular}{|c|c|c|}
\hline & TSu & TSa \\
\hline TEBU51 & $\begin{array}{c}\text { Thousands of } \\
\text { candidates are } \\
\text { excluding } \\
\text { themselves }\end{array}$ & $\begin{array}{c}\text { Ribuan kandidat } \\
\text { mengecualikan } \\
\text { diri }\end{array}$ \\
\hline TEBU52 & & $\begin{array}{l}\text { Ribuan kandidat } \\
\text { mengundurkan } \\
\text { diri }\end{array}$ \\
\hline TEBU53 & & $\begin{array}{l}\text { Ribuan calon } \\
\text { pekerja tidak } \\
\text { dapat masuk }\end{array}$ \\
\hline TETD51 & $\begin{array}{l}\text { Thousands of } \\
\text { candidates are } \\
\text { excluding } \\
\text { themselves }\end{array}$ & $\begin{array}{l}\text { Ribuan pekerja } \\
\text { menjauhkan diri } \\
\text { dari kesempatan }\end{array}$ \\
\hline TETD52 & & $\begin{array}{l}\text { Ribuan calon } \\
\text { pekerja } \\
\text { melewatkan } \\
\text { kesempatan }\end{array}$ \\
\hline TETD53 & & $\begin{array}{l}\text { Ribuan kandidat } \\
\text { menghilangkan } \\
\text { kesempatan }\end{array}$ \\
\hline
\end{tabular}

Data ini juga dapat menunjukkan adanya perbedaan kualitas padanan yang dihasilkan oleh mahasiswa yang cenderung menggunakan strategi membaca top-down dan yang cenderung menggunakan strategi bottom-up. Exclude menurut sebuah kamus online artinya to leave someone or something out of something; to leave someone or something off a list. Yang menarik dari kalimat ini adalah bentuk kalimat yang jarang ditemukan di BSa. Di BSu, sering kita temukan kalimat semacam I broke my leg, yang artinya tentu bukan subjek yang sengaja mematahkan kakinya. Hal ini juga sama dengan kalimat thousands of candidates are excluding themself. Tentu saja bukan subjek yang sengaja tidak mau mendapat kesempatan kerja, tetapi kesalah menulis merekalah yang menyebabkannya. Oleh karena itu, lebih tepat jika kalimat ini diterjemahkan menjadi ribuan pelamar kebilangan kesempatan mendapat pekerjaan.

\section{Kualitas Terjemahan Teks Naratif a. Kesepadanan Tataran Kata}

Tabel 6. Kesepadanan Tataran Kata

\begin{tabular}{ccc}
\hline & TSu & TSa \\
\hline TEBU61 & Sick & Sakit \\
TEBU62 & & Suram \\
TETD61 & Sick & Muak \\
TETD62 & & Perih \\
\hline
\end{tabular}

Ada beberapa pengertian kata sick menurut sebuah kamus daring www.macmillandictionary.com di antaranya adalah: (1) if you are sick, you do not feel well dan (2) if something that someone does or says is sick, it is so unpleasant that it would upset some people. Jika dilihat dari konteksnya, kalimat ini muncul ketika subjek melihat gadis yang ia sukai bergandengan tangan dengan pria lain. Dengan demikian, makna sick pada kalimat tersebut cenderung mengacu pada definisi yang kedua yaitu perasaan yang timbul ketika melihat orang lain mengatakan atau melakukan sesuatu yang tidak menyenangkan. Ada padanan yang cukup beragam untuk adjektiva ini. Jika sick pada kalimat ini diterjemahkan menjadi sakit atau perih, maka artinya penerjemah memilih menggunakan makna leksikal. Sementara jika diterjemahkan menjadi muak atau suram, penerjemah tampak berupaya memberikan padanan dengan makna kontekstual. Akan tetapi, untuk kata suram dapat dikatakan kurang tepat, karena menurut KBBI, definisi suram adalah (1) kurang terang (tentang cahaya); kurang kuat cahayanya; (2) kusam atau kuyu; dan (3) susah (tentang kehidupan); tidak tentu (tentang nasib, masa depan, dan sebagainya). Dari beberapa definisi tersebut tidak ada satu pun yang maknanya sesuai dengan definisi sick di bahasa sumber. Dengan demikian, padanan yang dianggap berterima adalah sakit, muak, dan perih karena ketiganya dapat mengandung makna figuratif yang menggambarkan kekesalan dan patah hati 
Tabel 7. Kesepadanan Tataran Kata

\begin{tabular}{ccc}
\hline & TSu & TSa \\
\hline TEBU71 & to bury & meletakkan \\
TEBU72 & & menyembunyikan \\
TETD71 & to bury & mengubur \\
TETD72 & & membenamkan \\
\hline
\end{tabular}

Ada beberapa definisi kata bury dalam kamus Mcmillan versi daring, di antaranya: (1) to dispose of by depositing in or as if in the earth; (2) to conceal by or as if by covering with earth; dan (3) to cover from view. Untuk memastikan makna yang paling tepat untuk kata bury pada kalimat ini maka perlu dijelaskan terlebih dahulu konteksnya. Kalimat ini muncul ketika subjek merasa patah hati setelah tidak sengaja melihat orang yang disukainya bergandengan tangan dengan orang lain dan berjalan ke arahnya. Di hadapannya ada sepiring xoi, dan it di kalimat tersebut mengacu pada hidangan tersebut. Dengan demikian, definisi yang tepat untuk kata bury di kalimat ini adalah nomor 3. Baik versi yang dihasilkan oleh strategi bottom up maupun top-down keduanya ada yang dianggap berterima dan ada yang tidak. Dari strategi bottom-up yang dianggap berterima adalah menyembunyikan karena lebih mendekati definisi to cover from view. Sementara dari strategi top-down yang lebih berterima adalah membenamkan karena menurut KBBI daring definisi membenamkan salah satunya adalah menghilangkan (membekukan, menyembunyikan, atau mendiamkan) perkara, urusan, dan sebagainya.

\section{b. Kesepadanan di Atas Tataran Kata}

Kata dead pada kalimat ini memiliki makna figuratif. Akan tetapi, dari padanan yang ada pada tabel di atas salah satunya memberikan padanan harfiah, yaitu mati. Padahal, jika diamati yang dimaksud dari kalimat itu adalah bahwa "pestanya membosankan" atau "pestanya tidak menyenangkan".
Tabel 8. Kesepadanan di Atas Tataran Kata

\begin{tabular}{lcc}
\hline & TSu & TSa \\
\hline TEBU81 & $\begin{array}{c}\text { The party was } \\
\text { dead }\end{array}$ & mati \\
& & \\
TEBU82 & & selesai \\
TETD83 & $\begin{array}{c}\text { The party was } \\
\text { dead }\end{array}$ & tidak \\
& menyenangkan \\
TETD84 & & membosankan \\
\hline
\end{tabular}

Sebagaimana definisi kata dead yang ada di kamus daring www.thefreedictionary.com, kata dead sebagai idiom dapat juga bermakna "quiet and uneventful; boring". Padanan lain yang dihasilkan dari strategi membaca bottom-up adalah selesai. Memang selesai bukan makna harfiah dari dead, akan tetapi padanan tersebut juga dianggap tidak berterima karena secara kontekstual tidak sesuai. Pada data ini terlihat kembali perbedaan kualitas padanan yang cukup signifikan antara yang dihasilkan dari membaca dengan strategi bottom-up dengan yang dihasilkan dari membaca dengan strategi top-down.

Tabel 9. Kesepadanan di Atas Tataran Kata

\begin{tabular}{ccc}
\hline & TSu & TSa \\
\hline TEBU91 & $\begin{array}{c}\text { "You didn't miss } \\
\text { much, Andy.” }\end{array}$ & $\begin{array}{c}\text { Kamu tidak } \\
\text { ketinggalan } \\
\text { banyak }\end{array}$ \\
& & Kamu tidak \\
TEBU92 & & terlalu \\
& & ketinggalan \\
TETD91 & "You didn't miss & Kamu \\
& much, Andy.” & beruntung \\
TETD92 & & Kamu tidak \\
& & ketinggalan \\
& & banyak \\
\hline
\end{tabular}

Ungkapan didn't miss much merupakan idiom yang biasa digunakan ketika seseorang melewatkan sebuah pengalaman yang ternyata tidak terlalu istimewa untuk dilakukan. Sebagaimana menurut kamus daring thefreedictionary.com, definisi dari ungkapan tersebut adalah "not to miss experiencing something that really was not worth experiencing anyway." Kalimat "you didn't miss 
much, Andy" diungkapkan oleh teman Andy yang baru saja pulang dari pesta ulang tahun teman mereka karena Andy tidak sempat datang. Dari keempat padanan yang diberikan baik dari padanan yang dihasilkan dari strategi membaca bottom-up maupun top-down, hanya ada satu padanan yang cukup mendekati, yaitu padanan dengan kode TETD91, kamu beruntung. Akan lebih tepat lagi jika ditambahkan menjadi "kamu beruntung tidak datang. Lagi pula pestanya membosankan." Atau "kamu tidak terlalu rugi kok, karena pestanya membosankan."

\section{c. Kesepadanan Gramatikal}

Tabel 10. Kesepadanan Gramatikal

\begin{tabular}{|c|c|c|}
\hline & TSu & TSa \\
\hline TEBU01 & $\begin{array}{l}\text { "I thought you } \\
\text { were going to the } \\
\text { birthday party." }\end{array}$ & $\begin{array}{c}\text { Saya pikir anda } \\
\text { akan pergi ke } \\
\text { pesta ulang } \\
\text { tahun. }\end{array}$ \\
\hline TEBU02 & & $\begin{array}{c}\text { Aku pikir kamu } \\
\text { akan pergi ke } \\
\text { pesta ulang } \\
\text { tahun. }\end{array}$ \\
\hline TETD01 & $\begin{array}{l}\text { "I thought you } \\
\text { were going to the } \\
\text { birthday party." }\end{array}$ & $\begin{array}{c}\text { Ayah pikir } \\
\text { kamu pergi ke } \\
\text { pesta itu }\end{array}$ \\
\hline TETD02 & & $\begin{array}{l}\text { Ayah pikir kau } \\
\text { pergi ke pesta } \\
\text { ultah itu. }\end{array}$ \\
\hline
\end{tabular}

Pada data kali ini yang menjadi fokus adalah bagaimana mahasiswa mencoba menerjemahkan pronomina yang sesuai dengan konteks. Menurut tata bahasa di bahasa Inggris, you dapat digunakan oleh siapa saja kepada siapa saja terlepas dari apakah ada jarak sosial yang berarti, apakah situasi formal atau informal, dan sebagainya. Di bahasa Indonesia, untuk kata ganti orang kedua cukup beragam bergantung pada konteks, setting, dan partisipan tuturannya. You bisa dipadankan dengan anda, kamu, kau, bahkan loe. Termasuk juga untuk kata ganti diri sendiri, bisa saya, aku, gue, atau sebutan kekerabatan atau kekeluargaan. Pada data kali ini, terlihat perbedaan kualitas padanan yang cukup signifikan. Padanan yang dihasilkan dari strategi membaca bottom-up cenderung bersifat harfiah tanpa mempertimbangkan konteks atau hubungan antar partisipan, yaitu saya, anda, $a k u$. Sementara padanan dari strategi membaca top-down dapat dianggap berterima karena sesuai dengan konteks, yaitu ayah, kamu, dan kau.

Tabel 11. Kesepadanan Gramatikal

\begin{tabular}{ccc}
\hline & TSu & TSa \\
\hline TEBU01 & "Andy, do you & Apakah kamu \\
& want to eat with & ingin makan \\
us?" & bersama kita? \\
TEBU02 & & Mau kah kau \\
& & makan bersama \\
& & kami? \\
TETD01 & "Andy, do you & Andi, kau mau \\
& want to eat with & makan bersama \\
& us?" & kami? \\
TETD02 & & Andi, apa kau \\
& & mau bergabung \\
& & bersama kami? \\
\hline
\end{tabular}

Jika data sebelumnya membahas mengenai kata ganti orang pertama dan kedua, kali ini yang dibahas adalah padanan kata ganti orang jamak. Di bahasa Inggris, us dapat mengacu pada penutur saja atau bisa juga untuk mengacu pada penutur dan petutur, sementara di bahasa Indonesia untuk menyebut pembicara dan yang diajak bicara menggunakan kita dan untuk menyebut yang berbicara dengan orang lain tanpa yang diajak bicara menggunakan kami. Untuk us di kalimat ini yang tepat adalah padanan kami karena mengacu pada pembicara dan orang lain tanpa yang diajak bicara.

\section{PENUTUP}

Dari hasil analisis yang telah dipaparkan dapat diketahui bahwa sebagian besar mahasiswa masih menunjukkan kecenderungan untuk menggunakan strategi bottom-up dalam proses menerjemahkan. Pada tahap awal membaca mereka cenderung berfokus 
untuk memahami arti kata per kata. Karena terlalu fokus pada arti kata, mereka jadi tidak mencoba mengaitkan pengetahuan yang baru dengan skemata atau pengetahuan terdahulu yang sudah mereka miliki. Mereka cenderung bergantung pada kamus setiap kali menemukan kata yang tidak mereka pahami. Ketika terlalu bergantung pada pemahaman arti kata, mereka akan kesulitan memahami makna teks secara utuh. Padahal proses membaca yang baik adalah ketika mereka mampu untuk membangun representasi mental yang koheren di benak mereka dari teks yang mereka baca (Mcnamara \& Kendeou, 2011). Hal ini dapat tercapai apabila mahasiswa sudah mampu memanfaatkan dengan maksimal strategi bottom-up dan topdown.

Pilihan strategi membaca dapat menghasilkan kualitas padanan yang berbeda. Salah satu contoh kasus adalah pada saat menerjemahkan kata atau ungkapan yang bermakna figuratif seperti "They are literally dead on arrival". Pada terjemahan yang dihasilkan oleh mahasiswa yang menggunakan strategi bottom-up, tampak kalimatnya sulit dipahami karena they diterjemahkan mereka dan dead diterjemahkan secara harfiah menjadi mati. Apabila mereka mencoba untuk menggabungkan keterampilan membaca bottom-up dan top-down tentu kekeliruan sepeti ini dapat dihindari. Dengan mencoba memanfaatkan pengetahuan yang sudah dimiliki untuk membantu proses membaca, mereka akan memahami bahwa they mengacu pada daftar riwayat hidup dan bahwasanya di bahasa Indonesia akan menjadi rancu ketika kata ganti benda menggunakan mereka, karena biasanya kata itu digunakan untuk kata ganti orang jamak.

Hasil analisis menunjukkan bahwa pilihan strategi membaca dapat mempengaruhi hasil terjemahan. Beberapa terjemahan yang dihasilkan oleh mahasiswa yang cenderung menggunakan strategi bottom-up dalam proses penerjemahan tidak sesuai konteks dan masih terkesan kaku dan tidak luwes. Sementara sekitar $80 \%$ terjemahan yang dihasilkan dari strategi top-down dianggap berterima karena sesuai dengan kaidah bahasa sasaran dan konteks kalimat. Selain itu, penelitian ini juga dapat menunjukkan bahwa sepenuhnya bergantung hanya pada salah satu strategi membaca dapat berpotensi menghasilkan terjemahan yang keliru.

Sayangnya, persentase mahasiswa yang menggunakan strategi top-down jauh lebih kecil dibandingkan dengan yang menggunakan strategi bottom-up. Bottom-up pada dasarnya dibutuhkan juga dalam proses membaca, akan tetapi tidak dapat dijadikan satu-satunya cara untuk menangkap makna yang utuh dari sebuah teks. Seringkali teks mengandung makna implisit yang tidak dapat dipahami hanya dari memahami kata per kata. Selain itu, dalam sebuah teks sering juga ditemukan kosa kata, frasa, atau ungkapan yang tidak dapat diterjemahkan kata per kata atau secara harfiah. Apabila tetap diterjemahkan secara harfiah, maka konsekuensinya pembaca sasaran akan merasa kesulitan memahami teks karena artinya rancu.

\section{DAFTAR PUSTAKA}

Baker, M. (1992). In Other Words: A Course book on Translation. London and New York: Routledge.

Colina, S. (2015). Fundamentals of Translation. UK: Cambridge University Press

Eskey, D., Devine, J., Carell, P. (1998). Interactive Approaches to Second Language Reading. UK: Cambridge University Press.

Hoed, B. (2006). Penerjemahan dan Kebudayaan. Jakarta: Dunia Pustaka Jaya.

Mcnamara, D., \& Kendeou, P. (2011). Translating Advances in Reading 
Comprehension Research to

Educational Practice. International Electronic Journal of Elementary Education 4(1).

Merriam, S. B. (1988). Case study research in education: a qualitative approach. San francisco: Jossey-Bass

Miles \& Hubermen. (1984). Qualitative data analysis: a source book of new methods. Beverly Hills: Sage.

Newmark, P. (1988). A text book of translation. UK: Prentice Hall Publishing.

Nida, E. A., \& Taber, C. R. (1982). The theory and practice of translation. Leiden :
Published for the United Bible Societies.

Nord, C. (1991). Text Analysis in Translation. Rodopi: Amsterdam.

Sugiyono .(2013). Metode Penelitian Kualitatif, Kuantitatif dan R\&D. Bandung: Alfabeta.

Tabata-Sandom, M. (2016). How do Learners of Japanese Read Texts When They Use Online Pop-Up Dictionaries? Reading Matrix: An International Online Journal, 16(2), 98109. 
